\title{
Transcription and Expression of the Exotoxin A Gene of Pseudomonas aeruginosa
}

\author{
By SHIN-TAI CHEN, ELZORA M. JORDAN, RUSSELL B. WILSON, \\ ROCKFORD K. DRAPER, AND ROYSTON C. CLOWES* \\ Biology Programs, The University of Texas at Dallas, Richardson, \\ Texas 75083-0688, USA
}

(Received 24 November 1986; revised I July 1987)

\begin{abstract}
The exotoxin A genes from Pseudomonas aeruginosa strains PA103 and PAO1 have been independently cloned in a pUC9-derived plasmid. In a non-toxigenic mutant of PAO1 as host, the cloned genes directed the synthesis of intact exotoxin A that expressed ADPribosyltransferase activity upon treatment with urea and dithiothreitol. Western-blot analysis of culture supernatants identified a polypeptide of $67 \mathrm{kDa}$, the molecular mass of intact exotoxin A. There was an approximately 15 -fold increase in the toxin yield from $P$. aeruginosa cells carrying a cloned PA103 gene compared to PA103, and a 40-fold increase in the yield of toxin from cells carrying a cloned PAO1 gene compared to PAO1; cells carrying the cloned PA103 gene yielded about four times more toxin than those carrying the cloned PAO1 gene. Toxin expression was correlated with the presence of a transcript that was initiated $88 \mathrm{bp}$ upstream from the translational start site. Little or no messenger RNA from either cloned gene could be detected in an Escherichia coli host, or in a $P$. aeruginosa host grown in the presence of $0.1 \mathrm{~mm}-$ $\mathrm{Fe}^{2+}$, a condition that inhibits toxin expression. The nucleotide sequences of two regions, each of approximately $500 \mathrm{bp}$, near the $5^{\prime}$ and $3^{\prime}$ termini of the structural gene were established. In these regions, the exotoxin A gene from PAOl has ten base-pair differences compared to the PA103 gene, three in the non-coding region, and seven in the structural gene, four of which should lead to amino-acid differences. No apparent sequence similarities were found between the inferred promoter region of the exotoxin A gene and that of other Pseudomonas genes, nor with the consensus sequence of $E$. coli promoters.
\end{abstract}

\section{INTRODUCTION}

Pseudomonas aeruginosa exotoxin A, like diphtheria toxin, exerts its lethal effect on mammalian cells by inhibiting protein synthesis. This inhibition results from the toxin-catalysed transfer of the ADP-ribosyl moiety of $\mathrm{NAD}^{+}$to elongation factor 2 (EF2), which blocks EF2 from further participation in protein synthesis (Iglewski \& Kabat, 1975; Vasil et al., 1977). While the enzymology of exotoxin A has been elucidated, it is not clear how the catalytic site of the toxin enters the cytosol to reach EF2, nor is the regulation of exotoxin A expression, which is controlled by iron, well understood. To better address questions of exotoxin A regulation and action, we (Mozola et al., 1984), and others (Gray et al., 1984) have been studying the cloned exotoxin A gene. We previously reported (Mozola et al., 1984) the cloning of a segment of the exotoxin A gene of $P$. aeruginosa strain PA103. This segment was expressed both in Escherichia coli and in $P$. aeruginosa, as measured by transfer of the ADP-ribosyl moiety of NAD ${ }^{+}$to EF2; but the polypeptide synthesized had a molecular mass of about $50 \mathrm{kDa}$, instead of the expected $67 \mathrm{kDa}$. We concluded that the carboxy-terminal region of the toxin had been cloned, and was fortuitously expressed from the tetracycline-resistance gene promoter of the vector pBR322.

Abbreviation: EF2, elongation factor 2. 
Concurrently, Gray et al. (1984) were successful in cloning and sequencing the entire exotoxin A gene from PA103 together with 746 bp upstream of the gene. The gene was expressed in $E$. coli under the control of the $E$. coli trp promoter. Thus, in these initial experiments expression of the cloned exotoxin A gene from its natural promoter had not been achieved.

We report here the cloning and characterization of $2.76 \mathrm{~kb}$ Pst I-EcoRI chromosomal fragments that encode the intact exotoxin A genes from $P$. aeruginosa strain PA103, the classical exotoxin-producing strain (Liu, 1966), and from a derivative of PAO1, the strain used for most genetic studies of this species (Holloway et al., 1979), including extensive studies related to exotoxin A (Bjorn et al., 1977, 1978; Gray \& Vasil, 1981; Hanne et al., 1983; Sokol et al., 1982). Both genes were expressed in a non-toxigenic derivative of $\mathrm{PAOl}$ from promoters located within the $2.76 \mathrm{~kb}$ cloned regions. A preliminary report of this work has appeared as $\mathrm{S}$. T. Chen, $\mathrm{E}$. Jordan, R. B. Wilson \& R. C. Clowes (1986), ASM Annual General Meeting, Abstract no. B-124.

\section{METHODS}

Bacterial strains and plasmids. E. coli $\mathrm{K} 12$ strain $\mathrm{HB} 101$ hsdS20 recA13 aral4 proA2 lacY1 galK2 rpsL20 xyl-5 $m t l-1$ supE44 $\lambda^{-} \mathrm{F}^{-}$(Boyer \& Roulland-Dussoix, 1969) was used for cloning and gene expression. The $P$. aeruginosa strains used are listed in Table 1. Strains PA103J and PAO286 were used as sources of the exotoxin A gene sequences studied. MAM2, a derivative of PAO286 that produces no exotoxin A, has a mutation that maps in or near the structural exotoxin A gene (toxA), and was described earlier (Mozola et al., 1984). To produce a Rec ${ }^{-}$ derivative of this mutant, we first constructed a donor strain, PAO1818, which carried the fertility factor R68.45, by transferring this factor from PAO8(R68.45). We then crossed PAO1818(R68.45) with MAM2, selecting for $\mathrm{Trp}^{+}$colonies, and screening for a $\mathrm{Thr}^{-}$colony which we designated MAM3. MAM3 was then mated with PTO66(R68.45), selecting for $\mathrm{Thr}^{+}$colonies, and screening cultures of recombinant colonies for a $\mathrm{Rec}^{-}$ phenotype by the ability to produce few or no prototrophic clones when transduced with a preparation of $F 116 \mathrm{~L}$ bacteriophage that was previously grown on a met- $28^{+}$strain, and which produced more than 100 prototrophic transductant colonies on MAM2 (Fruh et al., 1983). We designated one such $\mathrm{Thr}^{+} \mathrm{RecA}^{-}$colony, MAM4 (Table 1).

The plasmid pRO1614 was constructed by Olsen et al. (1982) by the insertion into the Pst I site of pBR322 of a $1.85 \mathrm{~kb}$ segment derived from a cryptic Pseudomonas plasmid. pRO1614 can replicate either in $E$. coli or $P$. aeruginosa (Olsen et al., 1982) and has been used in previous studies (Mozola et al., 1984; Wozniak et al., 1987). pRO1614 and pUC9 (Vieira \& Messing, 1982) were used for cloning and for the derivation of new vectors as described below.

Media. Nutrient agar contained (per litre) $25 \mathrm{~g}$ Oxoid Nutrient Broth no. 2, $5 \mathrm{~g}$ Difco yeast extract, and $12 \mathrm{~g}$ agar. Tryptic soy broth dialysate (TSBD) medium. (BBL: Becton Dickinson) deferrated with $\mathrm{CaCl}_{2}$, and supplemented with $0.1 \mathrm{M}$ monosodium glutamate and $1 \%(\mathrm{v} / \mathrm{v})$ glycerol was prepared as descibed by Iglewski \& Sodoff (1979). It was also supplemented with $1 \mathrm{~mm} \cdot \mathrm{MgSO}_{4}$, which was found to increase toxin yields approximately twofold (data not shown). TSBD medium was made inhibitory for exotoxin A production by the addition of $0 \cdot 1$

Table 1. P. aeruginosa strains used

\begin{tabular}{|c|c|c|}
\hline Strain & Genotype & Derivation or source \\
\hline PA103J & Prototrophic & G. Jacoby (Liu, 1966) \\
\hline PA103L & Prototrophic & S. Leppla (Liu, 1966) (PA103-22) \\
\hline PAO286* & $m e t-28$ trp -6 & B. Holloway (Stanisich \& Holloway, 1969) \\
\hline PAO1818* & leu-9001 pur-9013 thr-9001 & B. Holloway (Holloway et al., 1979) \\
\hline PAO8 & ilvD202 met-28 str-1 & $\begin{array}{l}\text { T. Morgan (Isaac \& Holloway, 1968) } \\
\text { (source of R68.45) (Haas \& Holloway, 1976; } \\
\text { Morgan, 1982) }\end{array}$ \\
\hline PTO66* & his-4 ilv-1118 lys-12 proA82 trp-6 recA102 & D. Haas (Fruh et al., 1983) \\
\hline MAM2* & met-28 trp-6 toxA & Mutagenesis of PAO286 (Mozola et al., 1984) \\
\hline MAM3* & met -28 thr -9001 toxA & Cross PAO1818(R68.45) $\times$ MAM $2 \dagger$ \\
\hline MAM4* & met -28 recA 102 tox $A$ & Cross PTO66 $($ R68.45) $\times$ MAM3† \\
\hline MAM32 & Prototrophic Tox ${ }^{-}$ & Mutagenesis of PA103J $\ddagger$ \\
\hline
\end{tabular}


$\mathrm{mM}^{-} \mathrm{FeSO}_{4}$. Solid TSBD was prepared by adding agarose (SeaKem) to $1 \cdot 2 \%(\mathrm{w} / \mathrm{v})$. Minimal glucose medium has been previously described (Holmans \& Clowes, 1979); it was supplemented as necessary with amino acids, each to a concentration of $20 \mu \mathrm{g} \mathrm{ml}^{-1}$. Where appropriate, disodium carbenicillin $(\mathrm{Cb})$ or tetracycline (Tc) was added to concentrations of $300 \mu \mathrm{g} \mathrm{ml}^{-1}$ and $50 \mu \mathrm{g} \mathrm{m} l^{-1}$, respectively.

Cloning procedures, Western-blot analysis, and assays of ADP-ribosyltransferase activity of exotoxin $A$. These procedures were as previously described (Mozola et al., 1984), with several modifications. Horseradishperoxidase-conjugated goat anti-rabbit IgG (Cappel) was used in place of ${ }^{125} \mathrm{I}$-labelled Protein A (Hawkes et al., 1982) to detect exotoxin-related polypeptides transferred to nitrocellulose. $\left[{ }^{3} \mathrm{H}\right] \mathrm{NAD}^{+}(\mathrm{New}$ England Nuclear), at a final concentration of $0.2 \mu \mathrm{Ci} \mathrm{ml}^{-1}\left(7.4 \mathrm{kBq} \mathrm{ml}^{-1}\right)$, was substituted for $\left[{ }^{14} \mathrm{C}\right] \mathrm{NAD}^{+}$in ADP-ribosyltransferase assays, and these assays were performed on supernatants from $P$. aeruginosa cultures grown at $32{ }^{\circ} \mathrm{C}$ (Liu, 1966).

DNA/DNA hybridization. To identify clones carrying exotoxin A gene sequences, transformed cells were transferred to nitrocellulose paper and screened by hybridization as described in Maniatis et al. (1982) with a DNA probe derived from the $520 \mathrm{bp} \mathrm{BamHI}$ fragment of the exotoxin A gene previously cloned in pRC345 (Fig. 1; Mozola et al., 1984). The purified fragment used as a probe was labelled with $\left[\alpha^{32} \mathrm{P}\right] \mathrm{dCTP}$ by nick-translation with $E$. coli DNA polymerase I following the procedures recommended by Bethesda Research Laboratories, the supliers of the nick-translation kit.

S1-nuclease mapping of RNA transcripts. The methodology of Berk \& Sharp (1977) as described in detail by Chen \& Clowes (1984) was employed, with several modifications when using RNA derived from $P$. aeruginosa strains. First, during the isolation of RNA from cells grown in TSBD, a heat pulse at $65^{\circ} \mathrm{C}$ for $20 \mathrm{~s}$ was found to be adequate to promote lysis of $P$. aeruginosa cells, rather than the $100^{\circ} \mathrm{C}$ pulse used to lyse $E$. coli (Dennis \& Nomura, 1975). Second, to accommodate the higher GC content of Pseudomonas DNA, the temperature at which RNA/DNA hybrids were allowed to form was increased from $50^{\circ} \mathrm{C}$ to $60^{\circ} \mathrm{C}$. RNA was isolated from cells after $19 \mathrm{~h}$ incubation in TSBD broth at $32^{\circ} \mathrm{C}$ using the conditions noted in Fig. 2.

Nucleotide sequencing. DNA was sequenced by the standard method of Maxam \& Gilbert (1980).

Construction of plasmid vectors. Several plasmid vectors capable of replication in both $E$. coli and $P$. aeruginosa were constructed from pUC 9 by inserting the $1.85 \mathrm{~kb}$ Pst I fragment from pRO1614, which confers upon pBR322 the ability to replicate in a variety of hosts (Olsen et al., 1982). Thus, pRC354 was constructed by ligating the 1.85 kb PstI fragment of pRO1614 into PstI-cleaved pUC9, and was shown to be able to replicate and confer carbenicillin resistance in $P$. aeruginosa hosts. pRC357 was derived from pRC354 by partial digestion with $P s t$, followed by removal of the cohesive ends by treatment with SI nuclease, blunt-end ligation with T4 DNA ligase and transformation into $P$. aeruginosa, selecting for carbenicillin-resistant $\left(\mathrm{Cb}^{\mathrm{r}}\right)$ clones. The plasmid DNA of a number of transformants was first screened to detect those derivatives in which PstI cleaved the DNA to linear monomers. Several such DNAs were further screened for the production, after PstI-EcoRI digestion, of a linear DNA fragment of near monomer size of $4.51 \mathrm{~kb}$. One such plasmid, which was concluded to have lost the Pst I site distal to the EcoRI site, was isolated, and was designated pRC357.

\section{RESULTS}

\section{Cloning the intact exotoxin $A$ gene in $p U C 9$}

From the data of Gray et al. (1984) it was predicted that the intact exotoxin A gene of $P$. aeruginosa would be carried on a $2.76 \mathrm{~kb}$ Pst I-EcoRI fragment. We digested chromosomal DNA from strain PAO286 with EcoRI and PstI, separated the fragments by agarose-gel electrophoresis, transferred the DNA to nitrocellulose, and identified a $2.76 \mathrm{~kb}$ fragment that hybridized with the nick-translated 520 bp BamHI fragment from pRC345 (Fig. 1). A $2.76 \mathrm{~kb}$ region from a similar gel was excised and the DNA was recovered by electroelution, purified, and ligated to a PstI-EcoRI-cleaved preparation of pUC9, followed by transformation of E. coli HB101. (We used pUC9 and derivatives of pUC9 in these experiments because attempts to clone directly into pRO1614 resulted in the spontaneous loss of part of the $2.76 \mathrm{~kb}$ insert, together with part of the tetracycline-resistance gene of the vector.) Of $4500 \mathrm{Cb}^{\mathrm{r}}$ transformants screened, approximately $5 \%$ hybridized with the $520 \mathrm{bp}$ probe, indicating the presence of exotoxin A gene sequences in these cell lines. Examination of plasmid DNA from ten of these colonies showed that each had acquired a plasmid of the size of pUC9 plus a $2.76 \mathrm{~kb}$ insert. To ensure that the $2.76 \mathrm{~kb}$ fragment was the correct one, the insert of one of these plasmid DNAs was digested with PstI, Eco RI, BamHI, Sal I or BglII. The fragments generated corresponded in size to those expected for the $2.76 \mathrm{~kb}$ Pst $\mathrm{I}-E c o$ RI exotoxin A gene fragment of PA103 DNA (Gray et al., 1984) (Fig. 1). pUC9 carrying the $2.76 \mathrm{~kb}$ fragment of PAO286 was designated 
(a)

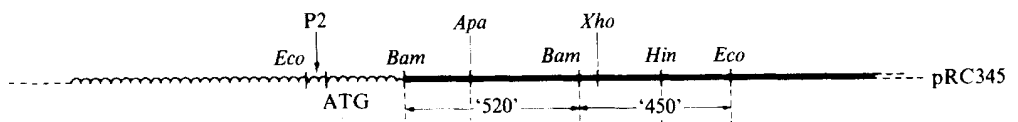

(b)

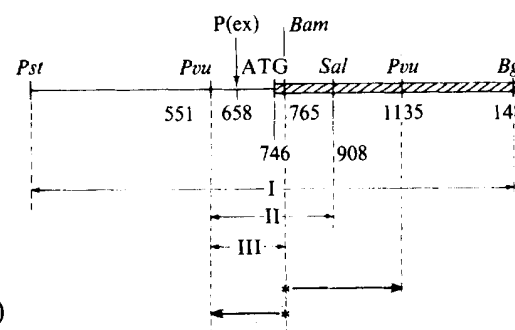

Fig. 1. Exotoxin A gene. (a) The segment cloned in pRO1614 to produce pRC345. Part of the cloned exotoxin A gene sequences is shown by the black bar; pRC1614 sequences are shown by the wiggly line. Eco, Bam, Apa, Xho and $H$ in are restriction-enzyme sites mapped for EcoRI, BamHI, ApaI, XhoI and Hinf I, respectively. The arrows spanning the ' 520 ' and ' 450 ' fragments represent those segments used as probes. $\mathrm{P} 2$ is the tet promoter in pBR322 and ATG is the start codon of the tetracycline-resistance gene. (b) The entire exotoxin A gene sequence as cloned on a $2.76 \mathrm{~kb}$ Pst I-EcoRI fragment (Gray et al., 1984). The numbers are nucleotides numbered from the $P s t I$ site. ( $P$ st, $P v u, S a l, B g l$ and $S a u$ represent cleavage sites for PstI, PvuI, SalI, BglI and Sau3AI, respectively.) The hatched double line represents the coding region of exotoxin $\mathrm{A}, \mathrm{ATG}$ the initiation codon and $\mathrm{P}(\mathrm{ex})$, the initiation site of exotoxin transcription. (c) I, II, III represent segments of the gene used as probes in S1-nuclease experiments. (d) The arrows represent the regions over which the nucleotide sequences were determined from the asterisked sites.

pRC350. pRC351 was constructed by ligating the $1.85 \mathrm{~kb}$ Pst I fragment of pRO1614 into PstIcleaved pRC350. pRC352 was isolated from pRC351 after deletion of the PstI site distal to the EcoRI site, as decribed for the construction of pRC357 from pRC354 (see Methods).

The exotoxin A gene from PA103 was cloned on a $10 \mathrm{~kb} E c o$ RI fragment of PA103J chromosomal DNA, which had been shown to hybridize with the $520 \mathrm{bp}$ fragment of pRC345. An EcoRI fragment was selected, since we found that chromosomal DNA isolated from two sources of PA103 (PA103J and PA103L) was not cleaved by $P$ st I. The $10 \mathrm{~kb} E c o$ RI fagment was ligated with an EcoRI-cleaved, alkaline-phosphatase-digested preparation of pUC9. After transformation of competent $E$. coli $\mathrm{HB} 101$ cells, $3000 \mathrm{Cb}^{r}$ clones were obtained, approximately $1 \%$ of which hybridized with the 520 bp probe. Plasmid DNA was isolated from eight clones and each was found to consist of a $10 \mathrm{~kb} E c o \mathrm{RI}$ fragment inserted into pUC9. One of these plasmids, designated pRC361, produced a $2.76 \mathrm{~kb}$ fragment when digested with EcoRI plus $P_{s t I}$. This fragment was isolated, purified, and cloned into PstI-EcoRI-cleaved pRC357 to produce pRC362, and into similarly cleaved pUC9 to produce pRC360. When digested with BamHI, KpnI, SalI, AvaI, BglII or DdeI, both pRC360 and pRC362 produced fragments with sizes consistent with the sequence information provided for the $2.76 \mathrm{~kb}$ Pst I-EcoRI fragment cloned by Gray et al. (1984). Similar cleavage-site correlations were found in the clones pRC350 and pRC352 derived from PAO286, except that one RsaI site (at nucleotide 1127) was missing, suggesting that the nucleotide sequences of the two genes from different sources were not identical; this was substantiated by nucleotide-sequencing studies (see below). Plasmid DNA from either $\mathrm{pRC} 352$ or $\mathrm{pRC} 362$ isolated from a MAM4 host could be readily cleaved with PstI. However, when a Tox ${ }^{-}$derivative of PA103, MAM32, was transformed with pRC352 or pRC362, and the plasmid DNA was reisolated, it could not be cleaved with PstI. We conclude that our sources of PA103, as distinct from that used by Gray et al. (1984), express a system for PstI site modification.

\section{ADP-ribosyltransferase activity from cloned DNA}

The ADP-ribosyltransferase activity produced by $P$. aeruginosa strains PA103, PAO286, the Tox $^{-}$derivative of PAO286, MAM4, carrying pRC352 or pRC362, and E. coli HB101 carrying pRC352 or pRC362 was measured in culture supernatants by assaying transfer of $\left[{ }^{3} \mathrm{H}\right] \mathrm{ADP}-$ 


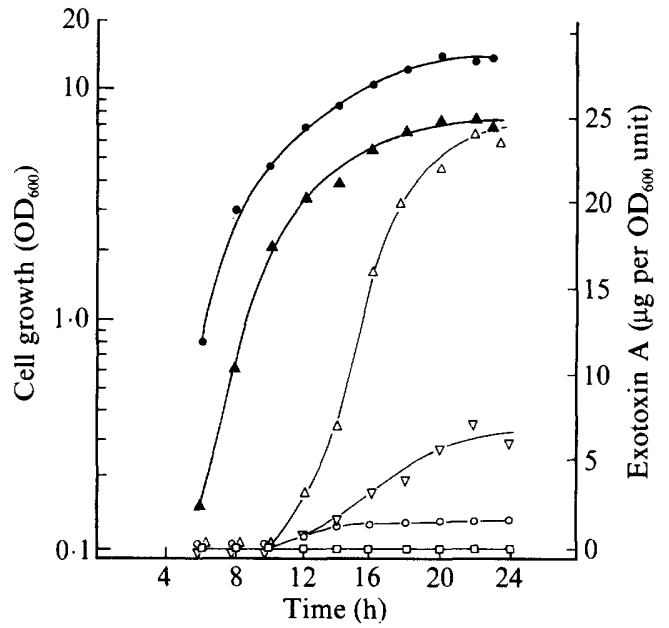

Fig. 2

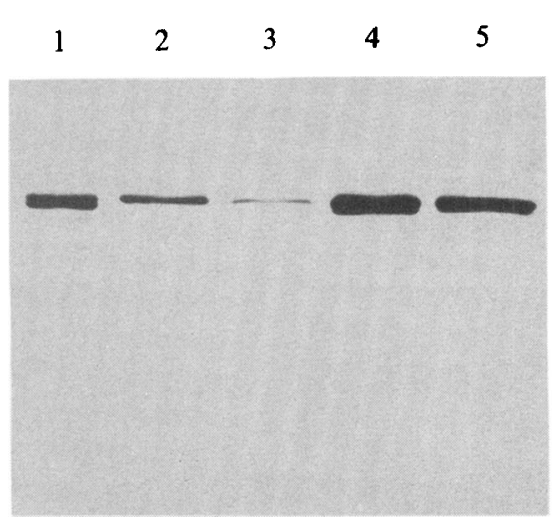

Fig. 3

Fig. 2. ADP-ribosyltransferase activities of various exotoxin-A-producing cultures as a function of growth. Overnight cultures in TSBD broth were diluted $1: 200$, subcultured in TSBD and incubated at $32{ }^{\circ} \mathrm{C}$ with aeration. At various times, samples were removed, diluted where appropriate, and assayed for culture density $\left(\mathrm{OD}_{600}\right)$ and for the ADP-ribosyltransferase activities of the supernatants (assessed as $\mu \mathrm{g}$ exotoxin $\mathrm{ml}^{-1}$ ). $, \Delta, \mathrm{OD}_{600}$ values for cultures of PA103 and MAM4(pRC362) respectively [growth of MAM4(pRC352) and PAO286 was similar to MAM4(pRC362)]. The open symbols represent ADP-ribosyltransferase activities expressed in terms of $\mu \mathrm{g}$ exotoxin $\mathrm{A}$ per $\mathrm{OD}_{600}$ unit, measured as previously described (Iglewski \& Sadoff, 1979), in supernatants of MAM4(pRC362) $(\triangle)$, MAM4(pRC352) ( $\nabla)$, PA103 (O) and PAO286( $\square$ ). The amounts of exotoxin A produced by PAO286 cultures were too small to be visible on this graph, but were well above the detectable level of $0 \cdot 05 \mu \mathrm{g}$ $\mathrm{ml}^{-1}$ - see Table 2 .

Fig. 3. Western-blot analysis of exotoxin A in culture supernatants. Procedures were as described by Mozola et al. (1984). Lane 1, $1 \mu \mathrm{g}$ purified exotoxin A. Lanes 2 to 5, 30 $\mu$ l supernatant from $150 \mathrm{ml}$ cultures grown as described and for which ADP-ribosyltransferase activities are shown in Table 2: lane 2, PA103; 3, PAO286; 4, MAM4(pRC362); 5, MAM4(pRC352).

\section{Table 2. ADP-ribosyltransferase activity in P. aeruginosa cultures}

The methodology was as described by Iglewski \& Sadoff (1979). Activity was measured in $10 \mu 1$ (diluted $1: 10$ or $1: 100$ as appropriate) of the supernatant of a $150 \mathrm{ml}$ culture derived from a $1: 200$ subculture of an overnight culture into TSBD and grown at $32^{\circ} \mathrm{C}$ for a further $20 \mathrm{~h}$, when exotoxin $\mathrm{A}$ activity reached a maximum (see Fig. 2).

\begin{tabular}{|c|c|c|c|}
\hline \multirow[b]{2}{*}{ Culture } & \multirow[b]{2}{*}{$\mathrm{OD}_{600}$} & \multicolumn{2}{|c|}{ ADP-ribosyltransferase activity* } \\
\hline & & $\left(\mu \mathrm{g} \mathrm{ml}^{-1}\right)$ & ( $\mu \mathrm{g}$ per $\mathrm{OD}_{600}$ unit) \\
\hline PAl03 & $14 \cdot 0$ & $20 \cdot 1$ & $1 \cdot 44$ \\
\hline PAO286 & $8 \cdot 4$ & 1.22 & $0 \cdot 145$ \\
\hline MAM4(pRC362) & $7 \cdot 4$ & 162 & $21 \cdot 90$ \\
\hline MAM4(pRC352) & $7 \cdot 5$ & $43 \cdot 7$ & $5 \cdot 83$ \\
\hline
\end{tabular}

* The amount of exotoxin A per sample was calculated using a standard curve of known concentrations of exotoxin $\mathrm{A}$; the results shown are the means of triplicate samples.

ribose from $\left[{ }^{3} \mathrm{H}\right] \mathrm{NAD}^{+}$to wheat-germ EF2 (Table 2, Fig. 2). As previously observed in PA103 cultures (Bjorn et al., 1978), exotoxin A synthesis was not detected until the early stationary phase of growth (Fig. 2) and no toxin $\left(<0.05 \mu \mathrm{g} \mathrm{ml}^{-1}\right)$ could be detected in any of the supernatants until the cell density exceeded $2 \times 10^{9}$ cells $\mathrm{ml}^{-1}$. In culture supernatants of PA103, there was an approximately tenfold greater concentration of exotoxin A (expressed as activity per cell mass) than in PAO286 cultures after $20 \mathrm{~h}$ of growth (Table 2 ). When the cloned genes were expressed in strain MAM4, there was a 15-fold increase in exotoxin A activity in 
cultures of cells carrying the cloned PA103 gene and a 40-fold increase in those of cells carrying the cloned PAO286 gene. When iron was added to $0 \cdot 1 \mathrm{~mm}$, toxin concentrations never exceeded, in any culture, more than $1 \%$ of those attained in cultures without added iron. No exotoxin A activity $\left(<0.05 \mu \mathrm{g} \mathrm{ml}^{-1}\right)$ was detected in cultures of $E$. coli $\mathrm{HB} 101$ carrying either of the cloned genes (data not shown).

\section{Western-blot analysis}

Supernatants derived from the exotoxin-A-producing cultures (Table 2) were subjected to SDS-PAGE and transferred to nitrocellulose. A single immunologically active band, which comigrated with purified exotoxin A, was found in preparations derived from PA103, PAO286, MAM4(pRC352) or MAM4(pRC362) (Fig. 3). The intensity of each band (Fig. 3) was roughly proportional to the ADP-ribosyltransferase activity of the samples (Table 2). No bands were visible when supernatant fluids of cultures of $E$. coli $\mathrm{HB101}$ (pRC362), or of $P$. aeruginosa strains that carried an active exotoxin $\mathrm{A}$ gene but which were grown in $0 \cdot 1 \mathrm{mM}-\mathrm{FeSO}_{4}$, were tested (data not shown).

\section{Determination of the site of transcriptional initiation}

Gray et al. (1984) determined that the initiating codon of exotoxin A began at base-pair 746 of the PstI-Eco RI fragment, with the first base-pair of this fragment designated as base-pair 1 (Fig. 1). The probe we initially used to determine whether transcription occurs in the region upstream of the initiating codon was a 1488 bp Pst I-Bgl II fragment (Fig. 1) isolated from pRC350 and 5'end-labelled at the $B g l$ II site only. S1-digestion experiments of the probe hybridized with RNA isolated from $P$. aeruginosa MAM4(pRC352) after $20 \mathrm{~h}$ subculture produced a protected sequence of $845 \pm 30$ nucleotides, indicating that transcription was initiated from nucleotide $645 \pm 30$ (data not shown). A smaller probe, consisting of the $357 \mathrm{bp} \mathrm{PvuI-SalI}$ fragment from pRC350, 5'-end-labelled at the SalI site only, produced a band of $253 \pm 10$ nucleotides under similar conditions with MAM4(pRC352) RNA (Fig. 4, lane 3), indicating that transcription had been initiated at nucleotide $655 \pm 10$. Bands of a similar size, but less intense, were also seen when RNA from PA103 or PAO286 cultures was used to protect this probe (Fig. 4, lanes 4 and 5). No bands of $253 \pm 10$ were seen when the RNA was derived from strain MAM4 carrying the vector pRC357, or from E. coli HB101(pRC352) (Fig. 4, lanes 7 and 8). Finally, a 214 bp PvuIBam HI fragment from pRC350 was used as the probe DNA with RNA from MAM4(pRC362) and this reaction was run in parallel with a nucleotide-sequence determination of that segment. From this experiment it was concluded that initiation of transcription takes place at nucleotide 658. An autoradiograph of this experiment is shown in Fig. 5. In parallel experiments, using RNA derived from toxigenic cultures which were grown in the presence of added $0 \cdot 1 \mathrm{~mm}-\mathrm{Fe}^{2+}$ and in which no toxin was produced, no protection of the DNA probe was seen. The result of such an S1 experiment using RNA derived from MAM4(pRC362) is also shown in Fig. 5.

\section{Nucleotide-sequence determinations}

pRC350 and pRC360 were each cleaved with BamHI to produce two fragments, one of 1530 $\mathrm{bp}$ (765 to 2295), and the other of $3890 \mathrm{bp}$ (including the vector plasmid) (Fig. 1). The fragments were end-labelled at the 5'-termini of the BamHI sites using T4-polynucleotide kinase and $\left[\gamma^{-32}\right.$ P]ATP. After cleavage with $P v u \mathrm{I}$, the four single, end-labelled fragments were separated and sequenced by the technique of Maxam \& Gilbert (1980).

The nucleotide sequence from 2020 to 2560 of pRC362 (from PA103J) was identical to that published for the PA103 strain used by Gray et al. (1984). The sequence in the same region of pRC352 (from PAO1) is almost identical, varying at only four positions: at 2287 there is a GC for AT substitution, and at 2341 a TA for CG substitution, neither of which should result in an amino-acid substitution; at 2039 there is an AT substitution for a GC which should substitute Ile in PAO286 for Val in PA103, and at 2363 there is substitution of GC for AT which should substitute Gly in the PAO286 sequence for Ser in the PA103 sequence. The 409 bp nucleotide sequence from nucleotides 553 to 961 of the PA103J strain used in this study was also identical to that determined by Gray et al. (1984). DNA from the analogous region of PAO286 differed in six 


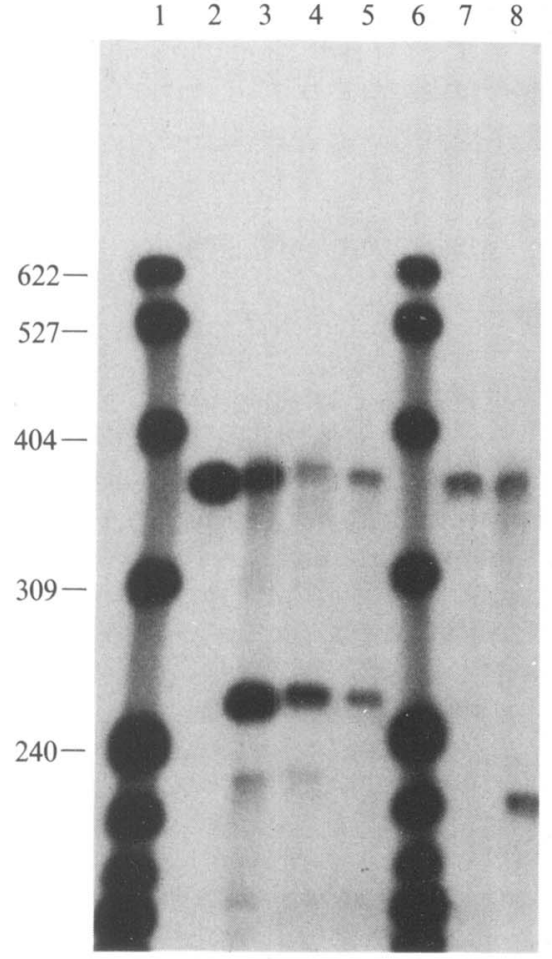

Fig. 4

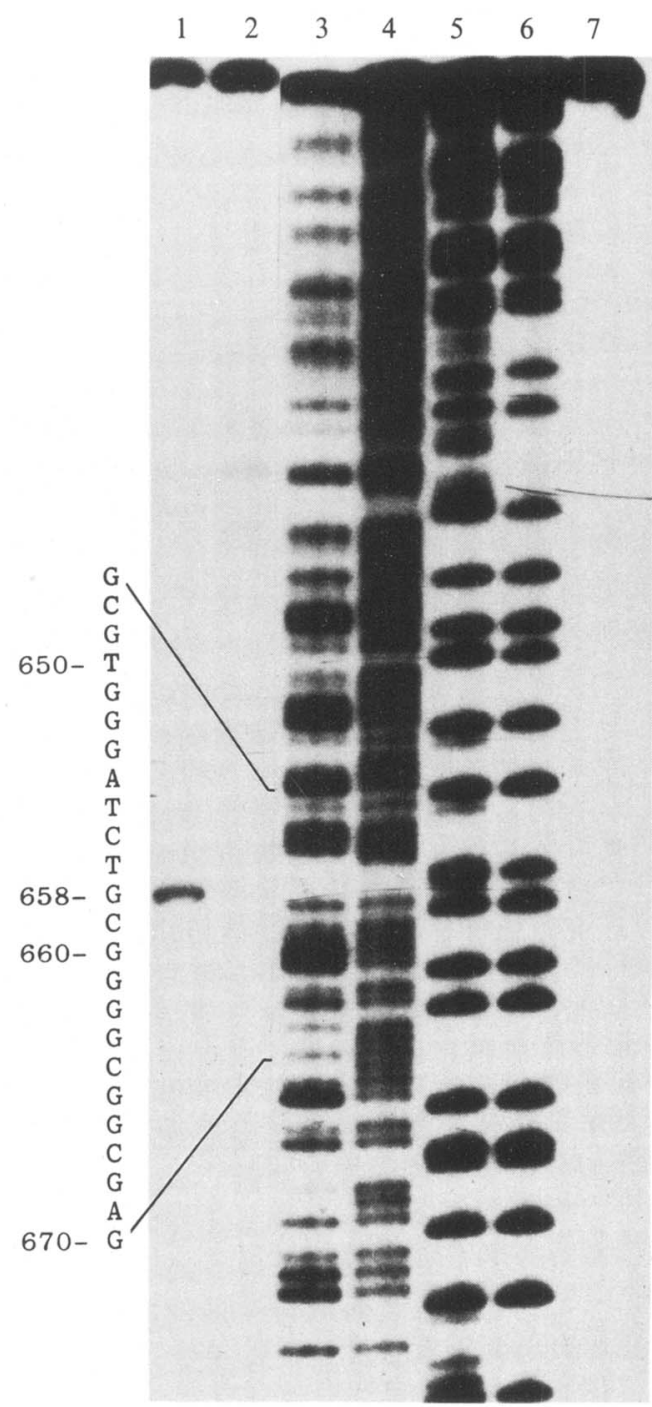

Fig. 5

Fig. 4. S1-nuclease assys of exotoxin A probe. Autoradiograph of urea polyacrylamide gel following separation of DNA of a 357 bp end-labelled PvuII-SalI fragment (probe II in Fig. 1c) after hybridization with RNA and digestion with S1 nuclease. Lanes 1 and 6, pBR322 HpaII standards with sizes (bp) shown at side. Lane 2, probe II $(0 \cdot 15 \mu \mathrm{l}) ;$ lanes $3,4,5,7$ and 8 were loaded with $7 \cdot 5 \mu$ lof probe II following its hybridization with RNA and S1-digestion. RNAs isolated after $19 \mathrm{~h}$ subculture were $60 \mu \mathrm{g}$ MAM4(pRC352) in lane $3 ; 175 \mu \mathrm{g} \mathrm{PA103}$ in lane $4 ; 100 \mu \mathrm{g} \mathrm{PAO} 286$ in lane $5 ; 84 \mu \mathrm{g}$ MAM4(pRC357) in lane 7; $100 \mu \mathrm{g} E$. coli HB101(pRC352) in lane 8. Bands in lanes 3, 4, 5, 7, 8 at $360 \mathrm{bp}$ are due to undigested probe. The identity of the band at about $220 \mathrm{bp}$ in lane 8 is unknown.

Fig. 5. Initiation site for exotoxin A mRNA transcription. RNA was isolated after $20 \mathrm{~h}$ incubation at $32^{\circ} \mathrm{C}$ from a subculture of MAM4(pRC362) grown in TSBD, or in TSBD with $0.1 \mathrm{mM}-\mathrm{Fe}^{2+}$, and the degree of protection of a ${ }^{32} \mathrm{P}$-labelled $214 \mathrm{bp} \mathrm{PvuI-BamHI}$ fragment (probe III in Fig. $1 \mathrm{c}$ ) from pRC 360 afforded after hybridization with this RNA was determined. A $50 \%$ urea $/ 8 \%$ polyacrylamide gel in TBE buffer was run under constant power $(45 \mathrm{~W})$ for $4 \mathrm{~h}$. After electrophoresis, the gel was exposed to Kodak XAR-2 film at $-70^{\circ} \mathrm{C}$ overnight. Lane 1, RNA from MAM4(pRC362) grown in TSBD; lane 2, RNA from MAM4(pRC362) grown in TSBD + $0 \cdot 1 \mathrm{mM}-\mathrm{Fe}^{2+}$; lanes 3, 4, 5, and 6, Maxam and Gilbert nucleotide sequence reactions for $G, G+A, T+C, C$, respectively; lane 7 , probe without $R N A$. The letters and numbers to the left of the photograph indicate the nucleotide sequence complementary to part of that shown in Fig. 6. 


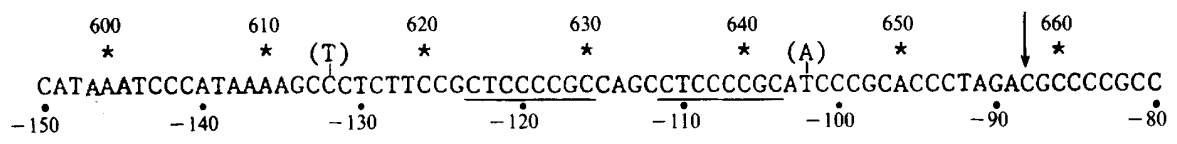

Fig. 6. Nucleotide sequence of part of the exotoxin A gene upstream of the initiating codon. The $5^{\prime}$ to $3^{\prime}$ sequence from nucleotide 596 to 666 shown is that for PA103 published by Gray et al. (1984) and confirmed in this study for PA103J. The numbers below the sequence indicate distances from the first base of the initiating codon at 746. The sequence of PAO286 is identical in this region, except at nucleotides 614 and 644, where the bases shown above the line in parentheses were found. The arrow above nucleotide 658 indicates the site inferred for the initiation of transcription of exotoxin A. The underlining indicates an 8 bp direct repeat.

positions from the sequence found for PA103J. Three of these differences were upstream of the coding region: TA instead of CG at position 614 , AT for TA at 644 , and AT for CG at 732 . The three differences in the coding region were CG for TA at 756 (which should result in the substitution of Ile by Thr), TA for CG at 810 (substituting Phe for Ser), and GC for AT at 859 (which should not result in a change of amino acid).

\section{DISCUSSION}

The exotoxin A genes from $P$. aeruginosa strains PA103 and PAO286 (a derivative of PAO1) have each been cloned on a $2.76 \mathrm{~kb}$ PstI-EcoRI fragment. The cleavage patterns of the genes of PAO286 (in pRC352) and of PA103 (in pRC362) for a number of restriction enzymes correspond to those of the PA103 gene reported by Gray et al. (1984) (see Fig. 1). The conclusion that the intact genes had been cloned was confirmed by measuring ADP-ribosylating activity (Table 2, Fig. 2) and the production of polypeptides which comigrated with purified exotoxin A (molecular mass $66583 \mathrm{Da}$, as predicted from the sequence of Gray et al., 1984), and interacted specifically with antibody to exotoxin A (Fig. 3). Moreover, these exotoxin-A-related polypeptides were synthesized in $P$. aeruginos $a$ hosts, but no similar product was seen when the plasmids were introduced into an $E$. coli host. This finding is consistent with the presence on the $2.76 \mathrm{~kb}$ Pst I-EcoRI cloned fragments of promoters for transcription of the exotoxin A genes which are recognized in $P$. aeruginosa, but not in $E$. coli.

The ADP-ribosyltransferase assays showed an approximately tenfold difference in the amounts of exotoxin A produced by PA103 compared to PAO286 (Table 2). When the exotoxin A genes of PA103 or PAO286 were cloned, exotoxin A synthesis increased approximately 15and 40-fold, respectively. This finding is consistent with a gene dosage effect due to the multicopy state of plasmids such as pRC357 and pRO1614 (Olsen et al., 1982), especially in cells in early-stationary-phase cultures, where increases in copy number occur (Lin-Chao \& Bremer, 1986). These results differ from those recently reported by Vasil et al. (1986), in which the PA103 gene was inserted into a pBR322/RSF1010 hybrid, multicopy plasmid, and the recombinant plasmid was introduced into the wild-type $P$. aeruginosa strain WR5, which appears to be deleted for exotoxin A gene sequences. This construct produced less exotoxin A than the parental PA103 strain, and the synthesis of the toxin was not reduced in media containing $10 \mu \mathrm{g}$ $\mathrm{Fe}^{2+} \mathrm{ml}^{-1}$. The reason for these discrepancies is unknown, but may be due to differences in the host strains used.

The presence of a promoter sequence on the cloned DNA was confirmed, and its position located, by the S1-nuclease experiments. The results of experiments in which RNA from toxigenic cultures was used to protect three defined probes are consistent with the initiation of transcription being within the cloned DNA at nucleotide 658, which is $88 \mathrm{bp}$ upstream of the translational initiation site (Figs 1, 4 and 6). It may also be concluded that initiation takes place at the same site on each of the cloned genes, and on the chromosomal genes of both PA103 and PAO286. However, we cannot exclude the possibility that the initiation site may be upstream of nucleotide 658, and that a longer transcript is synthesized and processed. [After this paper was submitted, Grant \& Vasil (1986) reported that exotoxin A mRNA transcription from the chromosomal gene of PA103 was initiated at 89 bp and at 62 bp upstream of the initiating codon.] 
The extent of exotoxin A synthesis in different cultures, measured either as enzyme activity (Table 2) or as the amount of immunologically cross-reacting protein (Fig. 3), is roughly paralleled by the level of transcription that may be inferred from S1-nuclease studies (Fig. 4). It seems likely, therefore, that the fourfold differences observed in the levels of enzyme activity in cells carrying the cloned genes from PA103 or PAO286 (Fig. 2) can be correlated with similar differences in the total exotoxin A protein synthesis (Fig. 3), which reflect the levels of mRNA transcription (Fig. 4). These differences may therefore result from quantitative differences in the regulation of exotoxin A synthesis, perhaps due to differences in the nucleotide sequences upstream of the coding regions of the genes.

The S1-nuclease experiments reported here show that in the presence of added iron, when exotoxin A production in $P$. aeruginosa is repressed, exotoxin A mRNA was reduced or absent in strains PA103 and PAO286, and also in a non-toxigenic host carrying a cloned exotoxin gene from either of these strains. This reduction in the level of mRNA may be due to inhibition of initiation of exotoxin transcription, or to enhanced degradation of the transcripts.

The sequence immediately upstream of the inferred site of transcriptional initiation at position 658 (Fig. 6) shows no obvious similarities to the consensus sequence for promoters recognized by the $\sigma^{70}$ RNA polymerase holoenzyme of $E$. coli (Hawley \& McClure, 1983; Rosenberg \& Court, 1979), and the sequence is particularly GC rich, in contrast to the ATrichness of the $E$. coli consensus promoter sequence. However, it may be noteworthy that this region carries a direct repeat of the sequence CTCCCCGC, and that within a region that would correspond approximately to the -10 box of the $E$. coli promoter consensus, there is a $T$ (at nucleotide 644) in the PA103 sequence, but an A in the PAO286 sequence. Also, 44 nucleotides upstream of the initiation site, at nucleotide 614, the PAO286 sequence has a $\mathrm{T}$ in place of the C in the PA103 sequence. It is possible that these sequence differences may affect RNA polymerase binding, which together with other differences in the regulatory region may influence the level of expression and contribute to the fourfold difference found between the expression of the two genes cloned from PA103 and PAO286 in the same host strain, MAM4.

Comparisons of sequences within this assumed promoter region of the exotoxin A gene also show no obvious similarities with other regions recently tentatively identified as promoters in Pseudomonas. These include promoters of the TOL plasmid [the $x y l A B C$ operon (Inouye et al., $1984 a$ ), the $x y l D E F G$ operon (Inouye et al., 1984b; Mermod et al., 1984) and the $x y l R$ regulatory gene (Inouye et al., 1985)]. However, sequence similarities between the promoter region of the exotoxin A gene and that of the aliginate (algD) gene of $P$. aeruginosa have recently been identified (Deretic et al., 1987). All these genes are only inefficiently expressed in $E$. coli, and regions resembling the $E$. coli $\sigma^{70}$-promoter consensus sequence have not been found, either in the region appropriately located to the site of transcriptional initiation, or in the region extending $100 \mathrm{bp}$ upstream of this.

There appear to be at least two types of sequences that can be recognized as promoters in $P$. aeruginosa. One type, characterized by the $\beta$-lactamase promoter on RP1, has close similarities with the consensus sequence of $E$. coli and is also recognized by $E$. coli RNA polymerase, probably by the holoenzyme with a $\sigma^{70}$ factor (Chen \& Clowes, 1987). The other type, as found in the exotoxin A gene, is clearly different and is not recognized by $E$. coli RNA polymerase. Since exotoxin $\mathrm{A}$ is not synthesized until early stationary phase, it is possible that its synthesis first requires the synthesis of a specific RNA polymerase, or of a $\sigma$-factor able to react with the core enzyme. Such a $\sigma$-factor would function as a positive regulator to increase exotoxin synthesis, like that identified as the product of the recently cloned toxR gene (Hedstrom et al., 1986; Wozniak et al., 1987).

\footnotetext{
We are grateful to Mark Mozola for the construction of a number of $P$. aeruginosa mutants, to George Jacoby, Stephen Leppla, Bruce Holloway, Tony Morgan and Dieter Haas who kindly supplied a number of $P$. aeruginosa strains, to Stephen Leppla for a gift of purified exotoxin A, and to A. M. Chakrabarty and D. R. Galloway for unpublished data. This work was supported by a Public Health Service grant from the General Medical Institute (GM32042), and by the Robert A. Welch Foundation (AT-879). The work is submitted in partial fulfilment of the PhD degrees of S.-T.C. and R.B.W.
} 


\section{REFERENCES}

BERK, A. J. \& SharP, P. A. (1977). Sizing and mapping of early adenovirus mRNAs by gel electrophoresis of S1 endonuclease-digested hybrids. Cell 12, 721-732.

BJoRn, M. J., VASIL, M. L., SADOFF, J. C. \& IGLEWSKI, B. H. (1977). Incidence of exotoxin production by Pseudomonas species. Infection and Immunity 16, 362-366.

BJoRn, M. J., IglewsKi, B. H., Ives, S. K., SADOFF, J. C. \& VASIL, M. L. (1978). Effect of iron on yields of exotoxin A in cultures of Pseudomonas aeruginosa PA103. Infection and Immunity 19, 785-791.

BOYer, H. W. \& Roulland-Dussoix, D. (1969). A complementation analysis of the restriction and modification of DNA in Escherichia coli. Journal of Molecular Biology 41, 459-472.

Chen, S.-T. \& Clowes, R. C. (1984). Two improved promoter sequences for beta-lactamase expression arising from a single base-pair substitution. Nucleic Acids Research 12, 3219-3234.

Chen, S.-T. \& Clowes, R. C. (1987). Variations between the nucleotide sequences of $\operatorname{Tn} 1, \operatorname{Tn} 2$ and Tn 3 and the expression of $\beta$-lactamase in Pseudomonas aeruginosa and Escherichia coli. Journal of Bacteriology 169, 913-916.

Dennis, P. P. \& Nomura, M. (1975). Regulation of the expression of ribosomal protein genes in Escherichia coli. Journal of Molecular Biology 97, 61-76.

Deretic, V., Gill, J. F. \& Chakrabarty, A. M. (1987). Pseudomonas aeruginosa infection in cystic fibrosis: nucleotide sequence and transcriptional regulation of the algD gene. Nucleic Acids Research 15, 4567-4581.

Fruh, R., Watson, J. M. \& HaAs, D. (1983). Construction of recombination-deficient strains of Pseudomonas aeruginosa. Molecular and General Genetics 191, 334-337.

Grant, C. C. R. \& Vasil, M. L. (1986). Analysis of transcription of the exotoxin A gene of Pseudomonas aeruginosa. Journal of Bacteriology 168, 1112-1119.

GraY, G. L. \& VASIL, M. L. (1981). Isolation and genetic characterization of toxin-deficient mutants of Pseudomonas aeruginosa PAO. Journal of Bacteriology 147, 275-281.

Gray, G. L., Smith, D. H., Baldridge, J. S., Harkins, R. N., Vasil, M. L., Chen, E. Y. \& Heyneker, H. L. (1984). Cloning, nucleotide sequence, and expression in Escherichia coli of the exotoxin A structural gene of Pseudomonas aeruginosa. Proceedings of the National Academy of Sciences of the United States of America 81, 2645-2649.

HaAs, D. \& Holloway, B. W. (1976). R factor variants with enhanced sex factor activity in Pseudomonas aeruginosa. Molecular and General Genetics 144, 243251.

Hanne, L. F., Howe, T. R. \& Iglewski, B. H. (1983). Locus of the Pseudomonas aeruginosa toxin A gene. Journal of Bacteriology 154, 383-386.

Hawkes, R., Niday, E. \& Gordon, J. (1982). A dotimmunoblotting assay for monoclonal and other antibodies. Analytical Biochemistry 119, 142-147.

Hawley, D. K. \& MCClure, W. R. (1983). Compilation and analysis of Escherichia coli promoter DNA sequences. Nucleic Acids Research 11, 2237-2255.

Hedstrom, R. C., Funk, C. R., Kaper, J. B.,
Pavlovskis, G. R. \& Galloway, D. R. (1986). Cloning of gene involved in regulation of exotoxin $A$ expression in Pseudomonas aeruginosa. Infection and Immunity 51, 37-42.

Holloway, B. W., Krishnapillai, V. \& Morgan, A. F. (1979). Genetics of Pseudomonas. Microbiological Reviews 43, 73-102.

Holmans, P. L. \& Clowes, R. C. (1979). Transposition of a duplicate antibiotic resistance gene and generation of deletions in plasmid R6K. Journal of Bacteriology 137, 977-989.

IGLEWSKI, B. H. \& KABAT, D. (1975). NAD-dependent inhibition of protein synthesis by Pseudomonas aeruginosa toxin. Proceedings of the National Academy of Sciences of the United States of America 72, $780-793$.

Iglewski, B. H. \& SAdoff, J. C. (1979). Toxin inhibitors of protein synthesis, production, purification, and assay of Pseudomonas aeruginosa toxin A. Methods in Enzymology 68, 780-793.

Inouye, S., NakaZaWA, A. \& NakazaWA, T. (1984a). Nucleotide sequence surrounding the transcription initiation site of $x y l A B C$ operon on TOL plasmid of Pseudomonas putida. Proceedings of the National Academy of Sciences of the United States of America 81, 1688-1691.

InouYe, S., Nakazawa, A. \& NaKaZaWa, T. (1984b). Nucleotide sequence of the promoter region of the $x y l D E G F$ operon on TOL plasmid of Pseudomonas putida. Gene 29, 323-330.

InOUYe, S., NakazaWa, A. \& Nakazawa, T. (1985). Determination of the transcription initiation site and identification of the protein product of the regulatory gene $x y l R$ for $x y l$ operons on the TOL plasmid. Journal of Bacteriology 163, 863-869.

IsaAC, J. H. \& Holloway, B. W. (1968). Control of pyrimidine synthesis in Pseudomonas aeruginosa. Journal of Bacteriology 96, 1732-1741.

LIN-ChAO, S. \& BREMER, H. (1986). Effect of the bacterial growth rate on replication control of plasmid pBR322 in Escherichia coli. Molecular and General Genetics 203, 143-149.

LIU, P. V. (1966). The role of various fractions of Pseudomonas aeruginosa in its pathogenesis. III. Identity of the lethal toxins produced in vitro and in vivo. Journal of Infectious Diseases 116, 481-489.

Maniatis, T., Fritsch, E. F. \& Sambrook, J. (1982). Molecular Cloning, a Laboratory Manual, pp. 314319, 326-328. Cold Spring Harbor, NY : Cold Spring Harbor Laboratory.

MaXAM, A. M. \& Gilbert, W. (1980). Sequencing endlabelled DNA with base-specific chemical cleavages. Methods in Enzymology 65, 499-560.

MERMOD, N., Lehrbach, P. R., ReineKe, W. \& TImmis, K. N. (1984). Transcription of the TOL plasmid toluate catabolic pathway operon of Pseudomonas putida is determined by a pair of coordinately and positively regulated overlapping promoters. EMBO Journal 3, 2461-2466.

MORGAN, A. F. (1982). Isolation and characterization of Pseudomonas aeruginosa R1 plasmid constructed by interspecific mating. Journal of Bacteriology 149, 654-661.

Mozola, M. A., Wilson, R. B., Jordan, E. M., 
Draper, R. K. \& Clowes, R. C. (1984). Cloning and expression of a gene segment encoding the enzymatic moiety of Pseudomonas aeruginosa exotoxin A. Journal of Bacteriology 159, 683-687.

Olsen, R. H., DeBusscher, G. \& McCombie, W. R. (1982). Development of broad-host-range vectors and gene banks, self-cloning of the Pseudomonas aeruginosa PAO chromosome. Journal of Bacteriology 150, 60-69.

Rosenberg, M. \& CourT, D. (1979). Regulatory sequences involved in the promotion and termination of RNA transcription. Annual Review of Genetics 13, 319-353.

Sokol, P. A., Cox, C. D. \& Iglewski, B. H. (1982). Pseudomonas aeruginosa mutants altered in their sensitivity to the effect of iron on toxin A or elastase yields, Journal of Bacteriology 151, 783-787.

Stanisich, V. A. \& Holloway, B. W. (1969)
Conjugation in Pseudomonas aeruginosa. Genetics 61, 327-339.

Vasil, M. L., Kabat, D. \& Iglewski, B. H. (1977). Structure-activity relationships of an exotoxin of Pseudomonas aeruginosa. Infection and Immunity 16, 353-361.

Vasil, M. L., Chamberlain, C. \& Grant, C. C. R. (1986). Molecular studies of Pseudomonas exotoxin A gene. Infection and Immunity 52, 538-548.

Vieira, J. \& Messing, J. (1982). The pUC plasmids, an M13mp7-derived system for insertion mutagenesis and sequencing with synthetic universal primers. Gene 19, 259-268.

Wozniak, D. J., Cram, D. C., Daniels, C. J. \& Galloway, D. R. (1987). Nucleotide sequence and characterization of tox $R$ : a gene involved in exotoxin A regulation in Pseudomonas aeruginosa. Nucleic Acids Research 15, 2133-2135. 